\title{
The Alleged Reference to the Tripartite Division of Jewish Law in 4QMMT
}

\author{
Michał Klukowski \\ The John Paul II Catholic University of Lublin \\ michal.klukowski@kul.pl \\ https://orcid.org/0000-0003-1130-7406
}

\begin{abstract}
חוק ומשפט וטהרה ABSTRACT: The article discusses Elisha Qimron's suggestion that the syntagm (B 52 = 4Q394 8 IV,2; 4Q396 1-2 II,3-4) from 4QMMT indicated the tripartite division of Jewish law in the understanding of the Qumran community. The first part presents the context of the use of 4QMMT, and briefly analyses the use of each of these terms in the literature of the Second Temple Period. The second part raises arguments refuting E. Qimron's idea and proposes an alternative meaning of חוק ומשפט וטהרה.
\end{abstract}

KEYwORDs: 4QMMT B 52; Jewish Law; hôq wûmišpāt; tohŏrāh

While many scholars have focused on the hypothesized tripartite division of the authoritative writings of Second Temple Judaism in 4QMMT (C 10 = 4Q397 14-21,10; 4Q398 14-17 I,2-3) as a textual witness to the early existence of a divided "canon" of the Scriptures, ${ }^{1}$ probably no one - as far as it has been feasible to establish - has taken up the issue

The article is a part of the project funded by the Ministry of Education and Science, Republic of Poland, "Regional Initiative of Excellence" in 2019-2022, 028/RID/2018/19, amount of funding: 11742500 PLN.

$1 \quad$ K. Berthelot, “4QMMT et la question du canon de la Bible hébraïque," From 4QMMT to Resurrection. Mélanges qumrâniens en hommage à Emile Puech (eds. F. García Martínez - A. Steudel - E.J.C. Tigchelaar) (STDJ 61; Leiden: Brill 2006) 1-14; G.J. Brooke, "The Explicit Presentation of Scripture in 4QMMT", Legal Texts and Legal Issues. Proceedings of the Second Meeting of the International Organization for Qumran Studies, Cambridge 1995. Published in Honour of Joseph M. Baumgarten (eds. J. Kampen - M.J. Bernstein - F. García Martínez) (STDJ 23; Leiden: Brill 1997) 85-88; J.G. Campbell, “4QMMTd and the Tripartite Canon," JJS 51 (2000) 181-190; C.A. Evans, "The Dead Sea Scrolls and the Canon of Scripture in the Time of Jesus," The Bible at Qumran. Text, Shape and Interpretation (ed. P.W. Flint) (SDSSRL 5; Grand Rapids, MI: Eerdmans 2001) 67-79; A. van der Kooij, "The Canonization of Ancient Books Kept in the Temple of Jerusalem," Canonization and Decanonization. Papers presented to the International Conference of the Leiden Institute for the Study of Religions (LISOR) held at Leiden 9-10 January 1997 (eds. A. van der Kooij - K. van der Toorn) (NB 82; Brill: Leiden 1998) 17-40; T.H. Lim, "The Alleged Reference to the Tripartite Division of the Hebrew Bible," RevQ 20 (2001) 23-37; T.H. Lim, "Authoritative Scriptures and the Dead Sea Scrolls," The Oxford Handbook of the Dead Sea Scrolls (eds. J.J. Collins - T.H. Lim) (Oxford: Oxford University Press 2010) 303-322; E. Ulrich, "Canon," EDSS I, 117-120; E. Ulrich, "Qumran and the Canon of the Old Testament," The Biblical Canons (eds. J.-M. Auwers - H.J. de Jonge) (BEThL 163; Leuven: Leuven University Press 2003) 57-80; E. Ulrich, 
of the alleged tripartite corpus of Jewish Iaw $^{2}$ in 4QMMT: in the syntagm ומשפט וטהרה (B 52 = 4Q394 8 IV,2; 4Q396 1-2 II,3-4). This tripartite division was noted by Elisha Qimron in the editio princeps, ${ }^{3}$ suggesting that each of the three nouns corresponds to one category of Jewish law, and the tripartite division itself implies a similar division present in the text of 1QS VI,22, namely, לתורה ולמשפט ולטוהרה. If both phrases factually related to the tripartite division of Jewish law, then - according to E. Qimron - the term תוק from 1QS VI,22 would be parallel to the term, statute") from 4QMMT, referring to the Law of Moses. ${ }^{4}$ In turn, the next two terms, משפט ("rule, judgment") and טהרה ("ritual purity"), common for 1QS and 4QMMT, would successively refer to civil law and the regulations of ritual purity. However, E. Qimron himself admits that the scope of each of these three terms within the alleged tripartite division of law, as understood by the Qumran community, ${ }^{5}$ requires in-depth research. The aim of the article is to determine whether the phrase חוק ומשפט וטהרה from 4QMMT can be interpreted as supposed evidence for the existence of a tripartite division of law in the light of the use of the three terms in Second Temple Judaism.

\section{The Context of the Use of חוק ומשפט וטהרה 4QMMT}

The aforementioned expression חוק ומשפט וטהרה appears in the legal section of the document 4QMMT, in the editio princeps marked with B, constituting the main corpus of the work. In this section, the authors give their addressees a proper legal interpretation concerning a number of issues related more or less to the Mosaic Law, which is not necessarily known in its present written version. One of the issues discussed by the authors is the problem of the status of the blind and deaf in the context of the temple worship and its sacrificial system (B 52-54). Under this system, some sacrificial offerings may be eaten, while some may not ${ }^{6}$; all this is governed by regulations that make up the "ordinances of Israel" - משפטי ישראל (B 53 = 4Q394 8 IV,3; 4Q396 1-2 II,4), including the laws of "the ritual purity of the sacred food"7 טהרת המקדש (B $54=4 Q 3948$ IV,4; 4Q396 1-2 II,6).

“The Non-attestation of a Tripartite Canon in 4QMMT," CBQ 65 (2003) 202-214; J.C. VanderKam, "Authoritative Literature in the Dead Sea Scrolls," DSD 5/3 (1998) 387-388.

2 Here Jewish law should be understood as law in the general sense, law to which the Jews were subject in Judea and which could have included both religious and civil regulations.

3 E. Qimron - J. Strugnell, Qumran Cave 4. V. Miqșat Ma' aśe ha-Torah (DJD 10; Oxford: Clarendon 1994) 52.

4 Qimron - Strugnell, Qumran Cave 4, 140.

5 It should be added that Elisha Qimron assumes that $4 \mathrm{QMMT}$ is a work created by the Qumran community. This assumption is not certain, but it is not necessary to authenticate or refute it in order to establish whether such a division of law, based on the expression הוק ומשפט וטהרה, functioned in Second Temple Judaism.

6 The Mishnah enumerates possible instances of unknowingly eating certain forbidden parts of the offering, including the sin offering referred to in 4QMMT (B $51=4$ Q394 8 IV,1). See m. Ker. 5,4-8.

7 Like in the Temple Scroll (11Q19 XLVII,17), טהרת המקדש refers to ritually clean foods to be sacrificed in the Jerusalem Temple. In 4QMMT this expression seems to a synonym of טהרת הקודש (B 65 = 4Q396 1-2 III,5; 4Q394 8 IV,15; B 68 = 4Q396 1-2 III,8; 4Q397 6-13,8), since in both cases the genitive of or- 
The blind, ${ }^{8}$ although are able to hear the law, cannot differentiate, due to their deformation, between all kinds of "mixture" of the food offerings (B 50 = 4Q396 1-2 II,2; cf. 4Q394 8 III,20 $)^{9}$ in the temple. In turn, the deaf cannot hear the ordinances of Israel, and thus they have no possibility of learning how to preserve these laws. Nevertheless, the authors of 4QMMT allow such persons to eat the food of the temple. ${ }^{10}$ It is in the context of the deaf that the phrase חוק ומשפט וטהרה was used to define the precepts that they cannot hear and obey them.

igin indicates sacral area. In the same meaning, the syntagm טהרת הקודש was used in 4Q513 2 II,1, and also in the Mishnah (Hag. 2,7), where it was used to regulations concerning the ritual purity of the food offerings. Hannah K. Harrington ( "Holiness in the Laws of 4QMMT", Legal Texts and Legal Issues. Proceedings of the Second Meeting of the International Organization for Qumran Studies, Cambridge 1995. Published in Honour of Joseph M. Baumgarten [eds. M.J. Bernstein - J. Kampen - F. García Martínez] [STDJ 23; Leiden: Brill

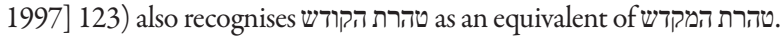

8 The additional description שאינם רואים "who cannot see" (B 50 = 4Q396 1-2 II,1-2; cf. B 51 = 4Q3948 IV,1) of the noun הסומים "the blind" (B 49=4Q394 8 III,20) specifies that the line is about those whose both eyes are deformed (Qimron - Strugnell, Qumran Cave 4, 52). Nonetheless, the Qumran community did not allow even those who were blind in one eye to participate in the sacrum (A. Shemesh, "'The Holy Angels Are in Their Council': The Exclusion of Deformed Persons," DSD 4 [1997] 179-206).

9 The text speaks precisely of כל תערובת "every mixture" (B 50 = 4Q396 1-2 II,2), but the context is clear that the mixture concerns the offering in the temple, which seems to be confirmed by the further expression "mixture of the guilt offering” (B 50-51 = 4Q396 1-2 II,2; 4Q394 8 III,20 - IV,1). Although the text first speaks of "every mixture," which causes that the addition of another category, i.e. "mixture of the guilt offering," seems illogical, the expression תערובת אשם can be an emphasis of the phrase "every mixture" and the conjunction waw before it can syntactically be interpreted in an emphatic way ("especially thus"). Therefore, the "mixture" concerning the guilt offering would be part of the aforementioned phrase, "every mixture." In this context it should be added that the very expression תערובת אשם is not attested outside 4QMMT, and thus it is not easy to establish its exact sense. It could have been a mixture of products included in the guilt offering mentioned, e.g. in Lev 5:6-26; 7:1-6 and 14:12-29. However, the fact is that no text certifies the use of the noun תערובת to designate elements of any offering, and so the hypothesis has thin grounds.

10 The position of the authors of 4QMMT does not only find any parallels in the remaining Qumran writings, but also in the Law of Moses and the Rabbinic texts. Although E. Qimron does not point to any biblical text that could support the legal problem (Qimron - Strugnell, Qumran Cave 4, 160-161), it cannot be excluded that here we are to a certain extent dealing with a reference to Lev 21:16-24. Since it says that a priest who has a defect (e.g. is blind; Lev 21:18), cannot fulfil his priestly function (Lev 21:23) by making offerings to God (Lev 21:21), but at the same time he may eat the most holy food of his God (Lev 21:22). Although 4QMMT does not suggest that the legal problem concerning the deaf and blind applies to priests, the authors of this document could have passed this priestly rule to lay people, but in this case, it should be assumed that they counted deafness as a "defect," while the expression טהרת המקדש relates to the food that was eaten by lay people, after the offering had been made, outside the temple. The blind were not permitted to enter the temple (see 2 Sam 5:8), and by analogy, the deaf could have been excluded as well. Yet, we cannot definitely refute the hypothesis that the text is about a blind or deaf person belonging to the priestly family who because of his deformation, inherited or acquired, could not be admitted to the ministry for the sake of maintaining the ritual purity of the holy food. 4QMMT seems to be a letter addressed to a person who has an influence on priests, as evidenced by the "formula of instructing priests" used several times, calling them to implement the guidelines of the authors of 4QMMT (see B 11-13 [4Q3943-7 I,14-16]; B 16-17 [4Q394 3-7 I,19 - II,1]; B 25-27 [4Q3943-7 II,13-14]; B 82 [4Q396 1-2 IV,11]). 


\section{The Terms חוק משפט and in the Literature of Second Temple Judaism}

The syntagm חוק ומשפט וטהרה is not attested outside 4QMMT, nor are there in any known texts from the Second Temple Period juxtaposing the nouns טשהרה משפט, משוק. Yet, it does not apply to the combination of the nouns משפט מוק, which occurs thirty-eight times in the Hebrew Bible ${ }^{11}$ and at least six times in the writings from Qumran, ${ }^{12}$ not counting the document 4QMMT (4Q394 8 IV,2 = B 52). Nevertheless, only in eight texts both nouns occur in their singular forms, again not counting $4 \mathrm{QMMT} .{ }^{13}$ Before discussing these

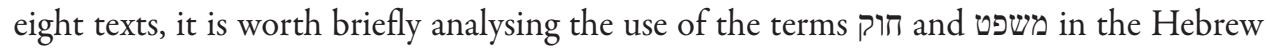
Bible and the Qumran writings.

In the Hebrew Bible the first term, חוק (from the root "to engrave," "to inscribe," "to establish") is used to designate rules and statutes, whether of divine origin - such as the laws of nature (e.g. Jer 33:25), the laws given to Moses (e.g. Exod 15:25-26), including priestly privileges and shares (e.g. Exod 29:28) - whether of human origin, such as civil laws (e.g. Gen 47:26), poetic rules (e.g. Sir 44:5), customs and manners (e.g. 2 Chr 35:25). A similar difference in the meaning of the noun be seen in the writings of the Qumran community, where it is used to denote the time and space frameworks decreed by God (e.g. 1QS X,1), including the laws of nature (e.g. 1QM X,12), as well as to describe the statutes of God's covenant (e.g. CD V,12), God's revelation (e.g. 1QpHab II,15), the cultic laws (e.g. 1QpHab VIII,10), the rules of communal life (e.g. 1QS V,20), and also the laws of the gentiles (e.g. CD IX,1) and the laws of [sons] of darkness (e.g. 1QM XIII,12). It is therefore a very broad term that generally refers to principles and rules which have an authority behind them and which therefore must be followed. ${ }^{14}$ However, this term is not attested as a specific and narrow category under general law. It is significant that in the Mishnaic texts, the term חוק has completely dropped out of use ${ }^{15}$ in favour of the term "judgment, argument, analogy" although it appears again in the Talmudic texts. ${ }^{16}$

In the legal context the second noun, משפט (from the root שפט, "to exercise power"), can refer to civil and religious laws, thus to God's laws (e.g. Exod 24:3) or to laws introduced by man (e.g. Ezek 11:12), including customs or accepted practices (e.g. 2 Kgs 17:26. 33-34). In the Qumran writings it occurs in the context of taking decisions (e.g. 1QS IX,7), giving judgement (e.g. 1QSa I,14), the result of a judgement, e.g. justification (e.g. 1QS XI,12), as well as the communal directives (1QS IX,10) and law as a moral norm expressing God's will

11 Exod 15:25; Lev 24:46; Num 9:3; Deut 4:1.5. 8.14.45; 5:1.31; 6:1.20; 7:11; 11:32; 12:1; 26:16.17; Josh 24:25; 1 Sam 30:25; 1 Kgs 2:3; 8:58; 9:4; 2 Kgs 17:37; Ezek 11:12; 20:18; 20:25; 36:27; Mal 3:22; Ps 81:5; 147:19; Ezra 7:10; Neh 1:7; 9:13; 10:30; 1 Chr 22:13; 2 Chr 7:17; 19:10; 33:8. All statistical data in the present article are based on Oaktree's software Accordance and its search capabilities.

12 CD XX,30; 1QSa I,5; 4Q184 5,5; 4Q400 1 I,5; 4Q504 3 II, 14; 11Q19 L,6.

13 Exod 15:25; Josh 24:25; 1 Sam 30:25; Ezra 7:10; Ps 81:5; 4Q184 5,5; 4Q365 6aII+6c, 11; 11Q19 L,6.

14 J.P. Lewis, "חקקק," TWOT I, 316-318; H. Ringgren, "חקק TDOT V, 139-147.

15 The exception is the text of $m$. Hul. 10,1, which is, however, a citation from Lev 7:34.

16 See M. Jastrow, "חוקו" DTTML I, 438. 
rooted in the Law of Moses (e.g. 1QS I,5). If in the legal context, משפט results from a divine bestowal, it refers to God's commandment or God's law in general, standing in parallel with terms such as תורה in both the Hebrew Bible and the Qumran texts. ${ }^{17}$ What is important here, like in the case of the noun משפט literature in favour of the aforementioned term דיקומין

In the context of the expression מוק ומשפט וטהרה, much more significant is the common use of the nouns משפט מקטים and which in the Hebrew Bible are attested mainly in the plural form - חקים ... ו ו... משפטים a precise designate of each of them. ${ }^{20}$ It seems that they both point to the law as a whole, for often these two plural nouns are used interchangeably or complementarily with such terms as מצוות "commandments," דברים "words, rulings," תורות "instructions" or עדות "testimonies. ${ }^{\prime 21}$ It is very difficult to precisely isolate the technical meaning of each of these terms within the collection of God's law because they have lost their specific and individual meanings in favour of their combinational use to denote law as a whole. ${ }^{22}$ In all this it is not clear whether the combination of the plural forms of the terms חשוק and משפט corresponds to their combinations in the singular forms with which we are dealing in the text of 4QMMT. In this context, it is worth attempting to show the usage of the terms חוק and משפט in their singular forms, which in turn will allow us to shed further light on the phrase 4QMMT.

\section{3. חוק ומשפט in the Literature of Second Temple Judaism}

The phrase in its singular form, חוק ומשפט, ${ }^{23}$ appears only in seven texts, but 4Q184 5,5 is too fragmentary to make any conclusion, while the fragment $4 \mathrm{Q} 3656 \mathrm{aII}+6 \mathrm{c}, 11$ is a citation from Exod 15:25. The latter mentions an event when the Israelites were given חוק ומשפט at

17 R.D. Culver, "שפטט," TWOT II, 947-949; B. Johnson, "משפט, TDOT IX, 86-98.

18 The term משפט can be found in the Mishnaic texts only ten times (see m. Sanh. 4,1;10,3;11,2; m. 'Ed.2,10 (x 5); 'Abot 1,18; 5,18), while the noun דין has been attested over 300 times. The Accordance module for the Mishna (MISH-T) is corrected to the Kaufmann Codex.

19 Lev 24:46; Deut 4:1.5. 8. 14. 45; 5:1. 13; 6:1.20; 7:11; 8:11; 11:1.32; 12:1; 26:16. 17; 30:16; 2 Kgs 17:37; Ezek 20:25; Mal 3:22; Neh 1:7; $1 \mathrm{Chr} 22: 13 ; 2 \mathrm{Chr} 19: 10 ; 33: 8$. In the Qumran texts this plural usage is attested in 4Q504 3 II, 14 .

20 Ringgren, "חקק", 142.

$21 \quad$ For example, Num 36:13; Deut 5:31; 6:1.17; 7:11; 8:11; 11:1; 26:17; 30:16; 1 Kgs 2:3; 6:12; 8:58; 2 Kgs 17:34. 37; 23:3; 1 Chr 28:7; 29:19; 2 Chr 8:14; 19:10; 34:31; Neh 1:7; 9:14. 29. 34; 10:30; Dan 9:5.

22 See the discussion of these problems with references in: Ringgren, "קקק," 142-145.

23 Exod 15:25; Josh 24:25; 1 Sam 30:25; Ezra 7:10; Ps 81:5; 4Q184 5,5; 4Q365 6aII+6c,11. Incidentally, one can only mention the presence of both nouns in the singular forms in the genitive construction, in which the nomen regens is the noun המשפט (Num 27:11; 35:29; 11Q19 L,6). In the Temple Scroll (11Q19 L,6), on the other hand, the verb טהר was used before the phrase חוק המשפט, which means that, exceptionally, there are exactly three roots next to each other, which make up the syntagm חוק ומשפט וטהרה from 4QMMT. 
the very beginning of their leaving Egypt, and here the very expression חוק ומשפט seems to refer to the Book of the Covenant (Exod 20:22-23:33) as its anticipation. The use of the phrase חוק ומשפט in Exod 15:25 testifies to the presence of the Deuteronomist, or D, (Deut 12-26), which was interwoven in the narrative created by the Priestly Code, or $\mathrm{P}^{24}$ and for which the phrase חוק ומשפט is a characteristic element although it usually occurs in the plural. ${ }^{25}$ A similar case can be observed in the Book of Leviticus (26:46), where in the only use of the phrase החקים והמשפטים, referring to the Book of the Covenant, this phrase does not belong to $\mathrm{P}$, but to $\mathrm{D}$, although the fragment itself is woven into the $\mathrm{H}$ narrative (Lev 17-26). ${ }^{26}$ In any case, the phrase Exod 15:25 seems to anticipate the Book of the Covenant because in both cases it is about the laws given by God through Moses.

The second passage, Josh 24:25, speaks about the covenant between Joshua and the people of Israel at Shechem. Within the covenant, Joshua reaffirmed for the Israelites חוק ומשפט. In this case, we could be dealing with a renewed covenant that God made with Moses, while חוק ומשפט would refer to the statutes included in this covenant. ${ }^{27}$ However, it seems that Josh 24:26 assumes that חוק ומשפט given by Joshua were added to - or more likely, constitute its part - the existing "the Book of the Law of God," ספר תורת אלהים, which in turn can refer to the law given by God at Mount Sinai. In this context, the probable function of Josh 24:25-26 would have been to relate Joshua's covenant (Judg 23-24) to the existing Sinai covenant, written in the Law of Moses. ${ }^{28}$

The third passage, 1 Sam 30:25, concerns the problem of the fair distribution of the spoils of war, which is solved by King David. The solution proposed by him is now חוק ומשפט for Israel. Here the context requires us to understand as a custom and practice, or possibly a royal ordinance. It is worth noting that the phrase is accompanied by the verb שים, which was also used in the syntagm in the analysed texts of Exod 15:25 and Josh 24:25. Moreover, like in the latter, in 1 Sam 30:25 the introduction of חוק ומשפט occurs as a result of a dispute or debate. ${ }^{29}$

According to the next passage (Ezra 7:10), Ezra arrives in Israel from Babylon to, on the one hand, study "the law of Yahweh," תורת יהוה, and on the other hand, to teach in Israel. The authors of Ezra-Nehemiah, in the context of their whole work, make people understand that Ezra brought the Law of Moses with him (cf. Neh 8:1; 9:3; 13:1), which at the time could have been understood as the Pentateuch, ${ }^{30}$ and which in the period of the redaction of Ezra-Nehemiah ( 3 rd c. BC) could have assumed the form

\footnotetext{
24 W. Johnstone, Exodus 1-19 (SHBC 2A; Macon, GA: Smyth \& Helwys 2014) 318; V.P. Hamilton, Exodus. An Exegetical Commentary (Grand Rapids, MI: Baker Academic Press 2011) 478-479.

25 Deut 4:1.5.8. 14.45; 5:1. 13; 6:1.20; 7:11; 8:11; 11:1.32; 12:1; 26:16. 17; 30:16.

26 J. Milgrom, Leviticus 23-27. A New Translation with Introduction and Commentary (AB 3B; New York: Doubleday 2001) 2342.

27 P. Pitkänen, Joshua (ApOTC 6; Nottingham: Apollos 2010) 454.

28 R.S. Hess, Joshua. An Introduction and Commentary (TOTC 6; Leicester: IVP 1996) 295.

29 A.G. Auld, I \& II Samuel (OTL; Louisville, KY: Westminster John Knox 2011) 342-343.

30 L.L. Grabbe, Ezra-Nehemiah (OTR; London: Routledge 1998) 139-143.
} 
חוק ומשפט is replaced by the syntagm דברי מצות־יהוה וחקיו "matters/words pertaining the commandments of the Lord and His statutes."

In the last, fifth passage, the author of Psalm 81 calls the Israelites to celebrate and sing for joy to God since God set free Israel from the Egyptian yoke. The probable context of the psalm was the Feast of Tabernacles. ${ }^{32}$ As Ps 81:4 says, the reason for the celebration is not only to remember the exodus from Egypt but above all the fact that celebrating this event means משפט and מוק for Israel, according to the ordinance of the God of Jacob when Joseph left Egypt (Ps 81:5[4]). Referring to the figure of Joseph and the title "God of Jacob" indicates that the psalm could have been created in northern Israel, but both its form and place in Asaph's collection seems to point to the post-exilic context of this psalm. ${ }^{33}$ Therefore, although in this text משפט rat משוק refer the local law of northern Israel, ${ }^{34}$ the connection of this psalm with Sukkoth and the associated joy in receiving the Law of Moses suggests that משפט may refer to the Pentateuch, like in Ezra 7:10.

This brief overview of the sporadic use of the combined משפט and מוק in the singular testifies to their different uses, whether for a set of covenant laws (Exod 15:25; Josh 24:25; Ezra 7:10) or for a single custom (1 Sam 30:25; Ps 81:4). Importantly, in the context of God's law, it is actually difficult to distinguish between the use of the terms משפט in their plural forms and their use in the singular. Therefore, it cannot be ruled out that their occasional use in the singular form is merely a stylistic procedure that essentially corresponds to the use of the nouns משפט חוק in the plural in the D material, i.e. with regard to law as a whole, consisting of the laws given by God through Moses. This interpretation of the phrase חוק ומשפט can allow us to assign each term to a specific category, class or type of the law, but the attempts made so far have not brought anything certain in this matter. ${ }^{35}$ Thus, it seems that the expression חוק ומשפט is best understood as it is represented in the plural form in the D material, as pertaining to the entirety of God's law, התורה, given by Moses. ${ }^{36}$

This observation seems to be confirmed by the very context of the above-mentioned texts of Exod 15:25, Josh 24:25 and Ezra 7:10, where חוק ומשפט is used in the context of the Law of Moses. So in Exod 15:25, the phrase חוק ומשפט in the next line would be repeated by the parallel מצותיו "His commandments" and כל־חקיו "all His statutes" (Exod 15:26);

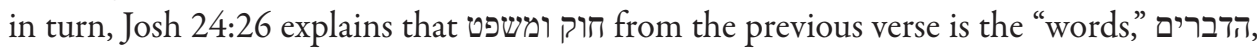
written "in the Book of the Law of God" - בספר תורת אלהים. Similarly, in Ezra 7:10, where

31 Grabbe, Ezra-Nehemiah, 146-147.

32 A.P. Ross, $A$ Commentary on the Psalms. II. (42-89) (KEL; Grand Rapids, MI: Kregel Academic 2013) 707; J.H. Waltner, Psalms (BCBC; Scottdale, PA: Herald 2006) 396.

33 Waltner, Psalms, 395.

34 Ross, A Commentary on the Psalms, 708.

35 Albrecht Alt and Gerhard Liedke uncertainly argued that the term משפט included "casuistic law," whereas the term "apodictic law." See the brief overview of the scholars' opinions in: Ringgren, "חקקוק," 142-143; cf. Johnson, "משפט," 94-95; Lewis, "חקקק", 317.

36 Ringgren, "חקקק," 145. 
in the next verse the phrase חוק ומשפט is explained as "words of the Lord's commandments and His statutes for Israel” - דברי מצות־יהוה וחקיו על־ישראל (Ezra 7:11). At this point, it is significant that a similar paradigm appears in 4QMMT, where in the next line the expression חוק ומשפט (B 52 = 4Q394 8 IV,2; 4Q396 1-2 II,3-4) was rendered with the parallel phrase משפטי ישראל "the ordinances of Israel" (B 53 = 4Q394 8 IV,3; 4Q396 1-2 II,4). This allows us to presume that in the passage of 4QMMT, the syntagm חוק ומשפט can also be a merism embracing all the laws of Israel. Yet, in this context we can ask about the kind of relation between the phrase טהרה and the noun ומשפט a i.e. about the meaning of the noun and its syntactic function in חוק ומשפט וטהרה חומטה.

\section{Is the Noun טהרה the Third Category of Law?}

In the Hebrew Bible, the noun טהר almost always refer to cultic purity. ${ }^{37}$ Depending on the context, it is used to denote a ritual or process of cleansing from ritual impurity, as well as to denote the time needed to obtain ritual purity or to denote ritually pure food. ${ }^{38}$ However, in no place can the use of the noun טהרה point to its understanding as a category of Jewish law. ${ }^{39}$ The fact that this is how E. Qimron understands the noun טהרה in 4QMMT seems to result from his assumption that this document is a work of the same community that created the Community Rule, which has the expression לתורה ולמשפט ולטוהרה (1QS VI,22). In this syntagm, the term תורה would refer to the Law משפט from 4QMMT, while the noun מוק משר could point to civil law, and the term טהרה would embrace laws concerning ritual purity. Nonetheless, E. Qimron's interpretation poses several problems.

Firstly, the origins of the 4QMMT document and the Community Rule in the same community is not certain. The position of the authors of 4QMMT, for example on the issue of the blind and deaf, in the context of the expression חוק ומשפט וטהרה evidently differs from what can be found in other writings of the Qumran community, where it is explicitly stated that the blind and deaf cannot enter its congregation (4Q266 8 I,7-9 = CD XV,16-17; 1QSa II,6). Moreover, the blind cannot participate in the eschatological war (1QM VII,4-5), and further, they are not permitted to enter Jerusalem (11Q19 XLV,12-14 $\left.4^{40}\right)$.

37 H. Ringgren “טהר," TDOT V, 287-296; E. Yamauchi, "טהרה"," TWOT I, 343-344; cf. "טהרה," HALOT II, 370; “טה:", DCH III, 348-349.

38 That is the food brought to the temple and stored there in the state of ritual purity so that it can later be eaten inside the temple; in this sense it is an equivalent of the biblical terms קדש קדשים.

39 טמא and The also applies to the Dead Sea Scrolls, see H.K. Harrington, "Semantic Field of the Lexemes in the Dead Sea Scrolls?", RevQ24/1 (2009) 97-114.

40 Tzvi Novick, wanting to reconcile the interpretations of the Temple Scroll and 4QMMT, rightly points out that the prohibition of the blind from entering the temple city, i.e. Jerusalem (11Q19 XLV, 12-14), is something other than the ban on contact with sacred food as the blind could potentially contact food destined for the temple outside Jerusalem (cf. 11Q19 XLVII, 2-8). According to T. Novick ("Overt Acknowledgement of Practical Considerations in Legal Texts from Qumran," DSD 21 [2014] 71-72), this ban could not be so much 
The consent of the authors of 4QMMT to allow the deaf and blind to eat the sacred food appears peculiar, ${ }^{41}$ which makes it difficult to assume that the texts of 4QMMT and the Community Rule are works of the same community. Consequently, the phrase ללטוהרה (1QS VI,22) does not necessarily constitute a proper comparative material to the phrase חוק ומשפט וטהרה (B 52 = 4Q394 8 IV,2; 4Q396 1-2 II,3-4) in the context of the division of Jewish law as understood by the Qumran community.

Secondly, the tripartite division of the law is questionable even in the text of 1 QSVI, 22 itself, ${ }^{42}$ which for E. Qimron is a point of reference. So, in the syntagm משורה ולמשפט ולטוהרה the term משפט may also refer to the issue of "judging, deciding" (cf. VI,23; VIII,25), while the term טהרה to eating ritually pure food (cf. V,13; VI,16-17; VII,3; VIII,17.24). Even if we follow E. Qimron and recognise that the noun מורה refers to the Law of Moses, משפט to civil law and טהרה to the law concerning ritual purity, it should be noted that the preposition seems to mark a fourfold division (לתורה ולמשפט ולטוהרה ולערב את הונו), in which all the four categories are strictly connected with the internal life of the Qumran community and correspond to the context of the entire text. Since on the one hand, the communal life is about "every affair involving the Law, property and judgment" כול דבר לתורה ולהון ולמשפט (V,3; cf. VI,24-25), and on the other hand, an expression of its unity is a communal feast with ritually pure food.

Thirdly, the expression מוק ומשפט וטהרה from 4QMMT evidently refers to the phrase משפטי ישראל, "the ordinances of Israel," which was used in the same context concerning the deaf and blind (cf. B 52 [= 4Q394 8 IV,2; 4Q396 1-2 II,3-4] and B 53 [= 4Q394 8 IV,3; 4Q396 1-2 II,4]). The very expression משפטי ישראל seems to be a reference to the Law of Moses since the authors of $4 \mathrm{QMMT}$ show their views exactly in relation to the Law of Moses, most likely to the text of Lev 21:16-24. Furthermore, the syntagm שמעו משפטי ישראל, whose subject is the deaf and blind, to a certain extent recalls Deut 4:1; $5: 1 ; 7: 12 ; 26: 17$, referring to the law Moses received from God. If we are to look for a parallel with חוק ומשפט וטהרה in the texts of the Qumran community, it would rather be the ex-

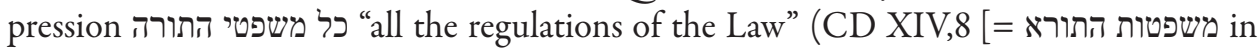
1QSa I,11?]) than the phrase from 1QS VI,26 (לתורה ולמשפט ולטוהרה ולערב את הונו), which seems to be much closer to the expression משפטי היחד, "the precepts of the community" (1QS VI,15), since the latter refer to the laws regulating the communal life of yahad.

Fourthly, in the light of the legal section of 4QMMT, the expression משפטי ישראל is most probably a reference to the Law of Moses as the precepts of this Law are explained by the authors of $4 \mathrm{QMMT}$; the possibility to interpret the term משפט in relation to civil law in the pharse חוק ומשפט וטהרה should be excluded. Moreover, my above and brief

about the fear of making sacrificial food unclean on the basis of its contact with the blind and deaf, but rather a fear that due to their deformation "the blind and deaf cannot keep the food apart from more severe forms of impurity."

41 Seen. 10.

42 The whole text: ואם יצא לו הגורל לקרבו ליחד יכתובהו בסרך תכונו בתוך אחיו לתורה ולמשפט ולטוהרה ולערב את הונו (1QS VI,22). 
analysis of the expression חוק ומשפט excludes the interpretation of the very term nוק referring to the Torah, as seen by E. Qimron, especially that the term itself is not attested in the meaning of the Torah, the Law of Moses, and in those places where it concerns the precepts included in the Law of Moses it usually occurs in the plural form. ${ }^{43}$

Fifthly, the authors of 4QMMT undoubtedly follow the Book of Deuteronomy, faithfully using the Deuteronomist's language. ${ }^{44}$ This allows us to assume that also חוק ומשפט is an expression of reaching for the language of the Deuteronomist, with the only difference that in the Book of Deuteronomy this expression appears in the plural, ${ }^{45}$ but this difference - as previously shown - does not seem to be reflected in the very semantic field of this expression. In this context, the entire expression חוק ומשפט וטהרה would not testify to the threefold division of the law but rather to the use of the Deuteronomist's expression וטהרה wוק ומשפט, to which the term added ${ }^{46}$ for reasons that will be discussed later.

Sixthly, no set division or classification of Judaic laws into some category is attested in Second Temple Judaism. In fact, one can found a classification of the biblical law in Josephus' Antiquities of the Jews (Books 3 and 4) and its thematic division in the Temple Scroll, but as David Altshuler proves, in both works the classifications are selective and completely subjected to the goals of the works, and thus they do not reflect any existing classification of Judaic laws from that period. ${ }^{47}$

Elisha Qimron, however, referring to m. Hag. 1,8, states: "The use of טהרה to denote a special class of laws suits the centrality of this realm in early halakha." ${ }^{48}$ Indeed,

43 See Ringgren "חקקו," 143-147.

44 For the relation between the Book of Deuteronomy and the text of 4QMMT, see: H. von Weissenberg, "4QMMT - Towards an Understanding of the Epilogue," RevQ 21 (2003) 29-45; H. von Weissenberg, "Deuteronomy at Qumran and in 4QMMT," Houses Full of All Good Things. Essays in Memory of Timo Veijola (eds. J. Pakkala - M. Nissinen) (Helsinki: Finnish Exegetical Society 2008) 520-537; H. von Weissenberg, 4QMMT. Reevaluating the Text, the Function and the Meaning of the Epilogue (STDJ 82; Leiden: Brill 2009) 120-143, 169-218; R.G. Kratz, "Mose und die Propheten: zur Interpretation von 4QMMT C," From 4QMMT to Resurrection. Mélanges qumraniens en hommage à Émile Puech (eds. F. García Martínez - A. Steudel - E.J.C. Tigchelaar) (STDJ 61; Leiden: Brill 2006) 151-176; R.G. Kratz, "'The Place which He Has Chosen': The Identification of the Cult Place of Deut. 12 and Lev. 17 in 4QMMT", Meghillot 5-6 (2007) 57-80.

45 See n. 25 .

46 In this context one should note that out of the seventeen usages of the phrase חקים ... ו ו משפטים in the Book of Deuteronomy (4:1. 5. 8. 14. 45; 5:1. 13; 6:1.20; 7:11; 8:11;11:1.32;12:1;26:16. 17;30:16), five is accompanied by a third element, i.e. the term עדה "testimony" (4:45; 6:20) or the term מצוה "commandment" (5:31; 6:1;7:11; 8:11;11:1;26:17;30:16). However, in no case are משפטק interchangeable with another term; the two concepts are inseparable from each other, which proves that they constitute a fairly well coined expression, perhaps even a merism defining the law as a whole. As for the noun מצוה "commandment," which at times goes together with the phrase חקים ... ו ... משפטים, in the light of Neh 10:30 it seems tantamount to this

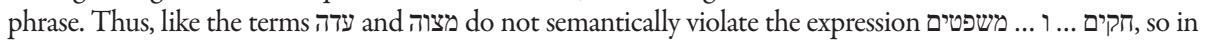
4QMMT the accompanying term טהרה does not seem to violate the expression מוק ומשפט, which has equally well been attested (Exod 15:25; Josh 24:25; 1 Sam 30:25; Ezra 7:10; Ps 81:5; 4Q184 5,5; 4Q365 6aII+6c,11 [= Exod 15:25]).

47 D. Altshuler, "On the Classification of Judaic Laws in the Antiquities of Josephus and the Temple Scroll of Qumran," AJSR 7/8 (1982/1983) 1-14.

48 Qimron - Strugnell, Qumran Cave 4, 140. 
the cited text of m. Hag. 1,8 includes the laws concerning what is "ritually pure and impure," הטהרות והטמאות, in the "essence of the Torah" - גופי תורה. Also, in the Amoraic period there were laws concerning ritual impurity (טומאה), and later Maimonides, dividing Jewish law in Mishneh Torah and Sefer ha-Miswot, distinguishes laws concerning "what is ritually impure and pure" - טהרה alone does not represent any known classification of the regulations pertaining to ritual cleanliness or uncleanness. It is true, however, that the concept of the tripartite division of law appears already in the Amoraic era, in which civil law is distinguished from religious law, including laws relating to ritual purity, ${ }^{50}$ but reading the phrase חוק ומשפט וטהרה in the same spirit at the pre-Tannaic stage seems to be an unauthorized imposition of a later pattern of thinking on the authors of $4 \mathrm{QMMT}$.

Considering the aforementioned objections, E. Qimron's hypothesis about the alleged tripartite division of the Jewish law, reflected in the phrase חוק ומשפט וטהרה from 4QMMT, seems to be poorly established in the light of the literature of Second Temple Judaism. Nonetheless, the rejection of this hypothesis inevitably leads to the previously asked question: as the expression חוק ומשפט is already well attested in the legal context at the time of the creation of $4 \mathrm{QMMT}$ (second half of the second century $\mathrm{BC}$ ), what is the relation between the noun טהרה and this expression? That is, what is the significance of the term טהרה ומשפט וטהרה in the whole expression and consequently, what is its syntactic function?

\section{The Significance of חוק ומשפט וטהרה in 4QMMT}

It is worth recalling once again that the expression חוק ומשפט וטהרה appears in the context of the deaf and blind who, due to their deformation, are unable to observe the regulations of the Mosaic Law relating to ritual purity. The deaf cannot hear the content of the regulations, while the blind, although they can hear them, cannot see and do not know whether they have had contacts with a person or items which are ritually unclean or not. The laws that the deaf are unable to hear and observe are expressed in חוק ומשפט וטהרה. Observ-

ומשני הגמרות ומן התוספתות ומספרא וספרי (ומן התוספות) מכולם יתבאר האסור והמותר הטמא והטהור החיוב והפטיור

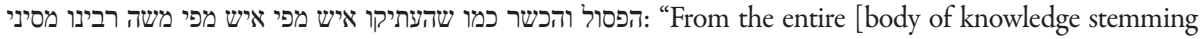
from] the two Talmuds, the Tosefta, the Sifra, and the Sifre, can be derived the forbidden and the permitted, the impure and the pure, the liable and those who are free of liability, the invalid and the valid as was received [in tradition], one person from another, [in a chain extending back] to Moses at Mount Sinai." [trans. E. Touget], Moses ben Maimon, Mishneh Torah (ed. E. Touger) (New York: Moznaim 2000, 1 ed. 1180); https://www.chabad.org/library/article_cdo/aid/901656/jewish/Introduction-to-Mishneh-Torah.htm [access: 13.07.2021]. Cf. the similar expression "טמא וטהר" also used in the context of the division of the Judaic laws; see Moses ben Maimon, Sefer ha-Mitzvot (Warsaw: Goldman 1883, 1 ed. 1497) 3; https://www.sefaria. org/Sefer_HaMitzvot?lang=bi [access: 13.07.2021].

50 "During the Amoraic period the notion of a threefold division of the law appears, namely: the ceremonial law (טיסורא), the laws of impurity (טומאה), and jurisprudence (ממונא)." B. Cohen, "The Classification of the Law in the Mishneh Torah," JQR 25/4 (1935) 523. 
ing חוק ומשפט וטהרה is shown to be key in assessing the permit for contact with the sacred food. As mentioned at the beginning, the authors of 4QMMT still admit the deaf and Blind to the sacred food, ${ }^{51}$ but here the key issue for us is the fact that ומשפט וטהרה should be understood in the context of the precepts on ritual purity, and therefore, in strict relation to the Mosaic Law as the source of these regulations.

Since there is no doubt that the authors of 4QMMT rely heavily on the language of the Book of Deuteronomy, it can be assumed that reflects the phrase חשקים .. ו ו ... משפטים, frequently used in it (see Deut 4:1. 5. 8. 14. 45; 5:1. 13; $6: 1.20 ; 7: 11 ; 8: 11 ; 11: 1.32 ; 12: 1 ; 26: 16.17 ; 30: 16)$, pertaining to the laws Moses received from God at Mount Sinai. As previously mentioned, one cannot see that the meaning and understanding of this phrase depend on the number used, be it singular or plural. Both the expression חוק ומשפט could have referred to the Mosaic Law, חוק ומשפט in the singular form is rendered with the parallel plural expressions related to the laws given by God (cf. Exod 15:25 and 15:26; Josh 24:25 and 24:26; Ezra 7:10 and 7:11). The same applies to 4QMMT, where in the next line the phrase מוק ומשפט (B $52=4$ QQ394 8 IV,2; 4Q396 1-2 II,3-4) is translated as the parallel phrase משפטי ישראל - "the ordinances of Israel" (B $53=4$ Q394 8 IV,3; 4Q396 1-2 II,4). This can allow us to assume that the syntagm should be interpreted in the relation to the already coined and well-attested expression חוק ומשפטי ${ }^{52}$

As the attention of the authors of 4QMMT in the context of the deaf and blind is focused on maintaining the ritual purity of the sacred food, ${ }^{53}$ it can be thought that they wanted to emphasize this category of law. However, since the entire legal section of 4QMMT deals with laws referring to the Mosaic Law, especially to the Book of Leviticus, Book of Numbers and Book of Deuteronomy, ${ }^{54}$ the mention of the law of ritual purity, טהרה, must take place within the framework of the Mosaic Law, and not alongside it. Otherwise it is difficult to understand why the authors of 4QMMT should cite the threefold division of Jewish law, including its civil law, משפט, since the halakhic context regarding the deaf and blind concerns the Mosaic Law itself. Further, if according to E. Qimron, the term nוק in the whole חוק ומשפט וטהרה would refer to the Torah, תורה could not

51 Seen. 10.

52 See n. 46.

53 Aharon Shemesh ("The Holy Angels Are in Their Council," 201, n. 60) interprets the whole halakha along this line, "Clearly, in this case, it is not the deformation which disqualify the blind and the deaf but rather the fear that the blind and the deaf, who cannot be precise in their observance of the laws of impurity, will accidentally desecrate the Temple and its holy offerings."

54 See J.M. Baumgarten, "The 'Halakha' in Miqșat Ma'ase ha-Torah," JAOS 116 (1996) 512-516; Bernstein, "The Employment and Interpretation of Scripture in 4QMMT: Preliminary Observations," Reading 4QMMT. New Perspectives on Qumran Law and History (eds.J. Kampen - M.J. Bernstein) (SymS2; Atlanta, GA: Scholar Press 1996) 29-51; Brooke, "The Explicit Presentation of Scripture in 4QMMT," 67-88. R.A. Kugler K.S. Baek, Leviticus at Qumran. Text and Interpretation (VTSup 173; Leiden: Brill 2017) 75-78.

55 Qimron - Strugnell, Qumran Cave 4, 140. It should be noted that E. Qimron consequently translates the term 4Q 4QMMT as "the Torah" (C 24, 27, 28) and even when it lacks the article (C 24, 28), which allows us 
constitute an equal category of the law within its threefold division because the laws regarding ritual purity are part of the Torah.

\section{Conclusion}

How should then the syntagm חוק ומשפט וטהרה in 4QMMT be interpreted and translated? In the context of the concern of the authors of $4 \mathrm{QMMT}$ about the sacred food, the term טהרה seems to be best understood as a regulation or a set of regulations concerning ritual purity within the Mosaic Law, ${ }^{56}$ which was expressed by the merism חוק ומשפט. Adequately, the aim of the added phrase וטהרה was to emphasise the regulations concerning ritual purity, related to the undertaken halakha. In this context, in חוק ומשפט וטהרה the conjunction waw before the noun טהרה would have an emphatic function ("and especially/particularly the laws concerning ritual purity"), or possibly an alternative function ("neither the laws ..."). Obviously, the expression חוק ומשפט does not necessarily constitute a merism, and the conjunction waw may well be treated in a combined function as a common "and." Nonetheless, even in such a case the term טהרה appears as a precept concerning ritual purity or at most a category of law within the Mosaic Law. However, it is certainly not part of the alleged tripartite division of Jewish law - both religious and civil - about which nothing is known in the light of the literature of Second Temple Judaism.

\section{Bibliography}

Altshuler, D., "On the Classification of Judaic Laws in the Antiquities of Josephus and the Temple Scroll of Qumran," The Association for Jewish Studies Review 7/8 (1982/1983) 1-14.

Auld, A.G., I \& II Samuel (Old Testament Library; Louisville, KY: Westminster John Knox 2011).

Baumgarten, J.M., "The 'Halakha' in Miqșat Ma ase ha-Torah (MMT)," Journal of the American Oriental Society 116 (1996) 512-516.

Bernstein, M.J., "The Employment and Interpretation of Scripture in 4QMMT: Preliminary Observations," Reading 4QMMT. New Perspectives on Qumran Law and History (eds. J. Kampen - M.J. Bernstein) (Symposium Series 2; Atlanta, GA: Scholar Press 1996) 29-51.

Berthelot, K., "4QMMT et la question du canon de la Bible hébraïque," From 4QMMT to Resurrection. Mélanges qumrâniens en hommage à Émile Puech (eds. F. García Martínez - A. Steudel - E.J.C. Tigchelaar) (Studies on the Texts of the Desert of Judah 61; Leiden: Brill 2006) 1-14.

to think that in his opinion the term factually represents the Torah as the Mosaic Law in the alleged tripartite division.

56 Thus similarly to the case of משפט הטהרה "precept concerning ritual purity" in 4Q514 1 I,6. When the authors want to specify an item of ritual purity within a given regulation, the noun טהרת is the nomen regens, like in the expressions included in 4QMMT, e.g. טהרת המקדש "ritually pure sacred/temple food" (B 54 = 4Q394 8 IV,4; 4Q396 1-2 II,6), טהרת הקודש "ritually pure sacred food" (B 65 = 4Q396 1-2 III,5; 4Q394 8 IV,15; B 68 = 4Q396 1-2 III,8; 4Q397 6-13,8). 
Brooke, G.J., "The Explicit Presentation of Scripture in 4QMMT" Legal Texts and Legal Issues. Proceedings of the Second Meeting of the International Organization for Qumran Studies, Cambridge 1995. Published in Honour of Joseph M. Baumgarten (eds. J. Kampen - M.J. Bernstein - F. García Martínez) (Studies on the Texts of the Desert of Judah 23; Leiden: Brill 1997) 67-88.

Campbell, J.G., "4QMMTd and the Tripartite Canon," Journal of Jewish Studies 51 (2000) 181-190.

Clines, D.J.A. (ed.), The Dictionary of Classical Hebrew. III. Zayin-Teth (Sheffield: Sheffield Academic Press 1996).

Cohen, B., "The Classification of the Law in the Mishneh Torah," The Jewish Quarterly Review 25/4 (1935) 519-540.

Culver, R.D., "שפט," Theological Wordbook of the Old Testament. II. Nun - Taw (eds. R.L. Harris - G.L. Archer, Jr. - B.K. Waltke) (Chicago, IL: Moody Press 1981) 947-949.

Evans, C.A., "The Dead Sea Scrolls and the Canon of Scripture in the Time of Jesus," The Bible at Qumran. Text, Shape and Interpretation (ed. P.W. Flint) (Studies in the Dead Sea Scrolls and Related Literature 5; Grand Rapids, MI: Eerdmans 2001) 67-79.

Grabbe, L.L., Ezra-Nehemiah (Old Testament Readings; London: Routledge 1998).

Hamilton, V.P., Exodus. An Exegetical Commentary (Grand Rapids, MI: Baker Academic Press 2011).

Harrington, H.K., "Holiness in the Laws of 4QMMT," Legal Texts and Legal Issues. Proceedings of the Second Meeting of the International Organization for Qumran Studies, Cambridge 1995. Published in Honour of Joseph M. Baumgarten (eds. M.J. Bernstein - J. Kampen - F. García Martínez) (Studies on the Texts of the Desert of Judah 23; Leiden: Brill 1997) 109-130.

Harrington, H.K., "What is the Semantic Field of the Lexemes טמא in and the Dead Sea Scrolls?," Revue de Qumrân 24/1 (2009) 97-114.

Hess, R.S., Joshua. An Introduction and Commentary (Tyndale Old Testament Commentaries 6; Leicester: IVP 1996).

Jastrow, M., Dictionary of Targumim, Talmud Babli and Yerushalmi, and Midrashic Literature (London: Luzac 1903) I-II.

Johnson, B., „משפט,", Theological Dictionary of the Old Testament. IX. Mem - Nun (eds. G.J. Botterweck H. Ringgren) (Grand Rapids, MI: Eerdmans 1998) 86-98.

Johnstone, W., Exodus 1-19 (Smyth \& Helwys Bible Commentary 2A; Macon, GA: Smyth \& Helwys 2014).

Koehler, L. - Baumgartner, W. - Stamm, J.J. (eds.), The Hebrew and Aramaic Lexicon of the Old Testament (Leiden - New York - Köln: Brill 1994) I-II.

Kratz, R.G., "Mose und die Propheten: zur Interpretation von 4QMMT C," From 4QMMT to Resurrection. Mélanges qumraniens en hommage à Émile Puech (eds. F. García Martínez - A. Steudel - E.J.C. Tigchelaar) (Studies on the Texts of the Desert of Judah 61; Leiden: Brill 2006) 151-176.

Kratz, R.G., "'The Place which He has Chosen': The Identification of the Cult Place of Deut. 12 and Lev. 17 in 4QMMT," Meghillot 5-6 (2007) 57-80.

Kugler, R.A. - Baek, K. S., Leviticus at Qumran. Text and Interpretation (Supplements to Vetus Testamentum 173; Leiden: Brill 2017).

Lewis, J.P., "חקקק," Theological Wordbook of the Old Testament. I. Aleph - Mem (eds. R.L. Harris - G.L. Archer, Jr. - B.K. Waltke) (Chicago, IL: Moody Press 1980) 316-318.

Lim, T.H., "The Alleged Reference to the Tripartite Division of the Hebrew Bible," Revue de Qumrân 20 (2001) 23-37.

Lim, T.H., "Authoritative Scriptures and the Dead Sea Scrolls," The Oxford Handbook of the Dead Sea Scrolls (eds. J.J. Collins - T.H. Lim) (Oxford: Oxford University Press 2010) 303-322. 
Milgrom, J., Leviticus 23-27. A New Translation with Introduction and Commentary (Anchor Bible 3B; New York: Doubleday 2001).

Moses ben Maimon, Mishneh Torah (ed. E. Touger) (New York: Moznaim 2000, 1 ed. 1180).

Moses ben Maimon, Sefer ha-Mitzvot (Warsaw: Goldman 1883, 1 ed. 1497).

Novick, T., "Overt Acknowledgement of Practical Considerations in Legal Texts from Qumran," Dead Sea Discoveries 21 (2014) 64-81.

Pitkänen, P., Joshua (Apollos Old Testament Commentary 6; Nottingham: Apollos 2010).

Qimron, E., - Strugnell, J., Qumran Cave 4. V. Miqsat Ma'aśe ha-Torah (Discoveries in the Judaean Desert 10; Oxford: Clarendon 1994).

Ringgren, H., "חקקץ," Theological Dictionary of the Old Testament. V. He - Yod (eds. G.J. Botterweck - H. Ringgren) (Grand Rapids, MI: Eerdmans 1986) 139-147.

Ringgren, H., "טהר," Theological Dictionary of the Old Testament. V. He - Yod (eds. G.J. Botterweck - H. Ringgren) (Grand Rapids, MI: Eerdmans 1986) 287-296.

Ross, A.P., A Commentary on the Psalms. II. (42-89) (Kregel Exegetical Library; Grand Rapids, MI: Kregel Academic 2013).

Shemesh, A., “'The Holy Angels Are in Their Council': The Exclusion of Deformed Persons from Holy Places in Qumranic and Rabbinic Literature," Dead Sea Discoveries 4 (1997) 179-202.

Ulrich, E., "Canon," Encyclopedia of the Dead Sea Scrolls (eds. L.H. Schiffman - J.C. VanderKam) (New York: Oxford University 2000) I, 117-120.

Ulrich, E., "The Non-attestation of a Tripartite Canon in 4QMMT," Catholic Biblical 2uarterly 65 (2003) 202-214.

Ulrich, E. "Qumran and the Canon of the Old Testament," The Biblical Canons (eds. J.-M. Auwers - H.J. de Jonge) (Bibliotheca ephemeridum theologicarum lovaniensium 163; Leuven: Leuven University Press 2003) 57-80.

Van der Kooij, A., "The Canonization of Ancient Books Kept in the Temple of Jerusalem," Canonization and Decanonization. Papers presented to the International Conference of the Leiden Institute for the Study of Religions (LISOR) held at Leiden 9-10 January 1997 (eds. A. van der Kooij - K. van der Toorn) (Numen Book 82; Brill: Leiden 1998) 17-40.

VanderKam, J.C., "Authoritative Literature in the Dead Sea Scrolls," Dead Sea Discoveries 5/3 (1998) 382-402.

Waltner, J.H., Psalms (Believers Church Bible Commentary; Scottdale, PA: Herald 2006).

von Weissenberg, H., "4QMMT - Towards an Understanding of the Epilogue," Revue de Qumrân 21 (2003) $29-45$.

von Weissenberg, H., "Deuteronomy at Qumran and in 4QMMT", Houses Full of All Good Things. Essays in Memory of Timo Veijola (eds. J. Pakkala - M. Nissinen) (Helsinki: Finnish Exegetical Society 2008) 520-537.

von Weissenberg, H., 4QMMT. Reevaluating the Text, the Function and the Meaning of the Epilogue (Studies on the Texts of the Desert of Judah 82; Leiden: Brill 2009).

Yamauchi, E., "טהר," Theological Wordbook of the Old Testament. I. Aleph-Mem (eds. R.L. Harris - G.L. Archer, Jr. - B.K. Waltke) (Chicago, IL: Moody Press 1980) 343-344. 
